\title{
Building Community Across the Battle-Lines: The Truce in Iliad 3 and 4
}

\section{Citation}

Elmer, David. 2012. Building Community Across the Battle-Lines: The Truce in Iliad 3 and 4. In Maintaining Peace and Interstate Stability in Archaic and Classical Greece, ed. Julia Wilker, 25-48. Mainz: Verlag Antike.

\section{Permanent link}

http://nrs.harvard.edu/urn-3:HUL.InstRepos:33921641

\section{Terms of Use}

This article was downloaded from Harvard University's DASH repository, and is made available under the terms and conditions applicable to Open Access Policy Articles, as set forth at http:// nrs.harvard.edu/urn-3:HUL.InstRepos:dash.current.terms-of-use\#OAP

\section{Share Your Story}

The Harvard community has made this article openly available.

Please share how this access benefits you. Submit a story.

Accessibility 
Building Community Across the Battle-Lines: The Truce in Iliad 3 and 4

Recent work on interstate relations in early Greece has produced two major revisions of established positions. The first is a welcome reassessment of Bruno Keil's often-cited characterization of peace as "a contractual interruption of a (natural) state of war." As Victor Alonso has stressed, war was only one possible mode of interaction for early Greek communities, and no more the default than either friendship or the lack of a relationship altogether. ${ }^{2}$ The second major development is represented by Polly Low's reconsideration of the widespread assumption that "a strict line can be drawn between domestic and international life": her work reveals the many ways in which Greek political life blurred the boundaries between intra- and inter-polis relationships. ${ }^{3}$ From a certain point of view, these two reconfigurations can be seen to be mutually reinforcing. The notion of a default state of war presupposes a clear line of demarcation between the community and its enemies. Thus, if the Athena of Aeschylus' Eumenides can promote the idea of an Athens more or less perpetually at war ("let there be foreign war, without stint," 864$)^{4}$, it is in the context of the play's construction of a civic body that is both internally cohesive and distinct from all others. The vision of the polis as a self-contained entity makes it possible to imagine a permanent, natural state of war. If, however, the boundaries of early Greek communities are not as clearly articulated as Aeschylus' vision implies, then the prospect of a default relationship between communities becomes correspondingly more elusive.

\footnotetext{
${ }^{1}$ Keil 1916, 8.

${ }^{2}$ Alonso 2007. See also Baltrusch 1994, 94, with references.

${ }^{3}$ See Low 2007, esp. Ch. 3; my quotation is from pp. 129-30.

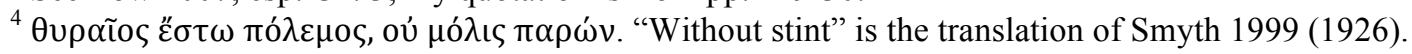


In fact, the Iliad speaks both to the vigor with which early Greek thought explored the possibility of alternatives to war, and to the fluid conception of community that supported such thinking. The poem expresses a discernible longing for peace, particularly in Books 3 and 4, when the Achaeans and Trojans struggle to establish and maintain philotês ("friendship") amongst themselves. This episode provides one of the principal examples exploited by Alonso in his critique of Keil. Alonso nevertheless holds to a conception of philotês as a "bond with a bilateral character," that is, as a reciprocal relationship between distinct groups. ${ }^{5}$ In so doing, he loses sight of the most distinctive feature of the Argive-Trojan entente: what is at stake is not so much the reconfiguration of a relationship between communities as the establishment of a new, higher-order community, one which incorporates both sides. Although this community ultimately proves unsustainable, for a short period of time it provides a framework for the peaceful interaction of its members. The present contribution seeks to delineate the terms in which the emergence of this broader community is expressed, and to provide some reflection on the meaning of its ultimate non-viability.

\section{Speaking with a common voice}

When the Trojans and Achaeans are finally on the verge of joining battle, at the beginning of Book 3, Hektor rebukes Alexander for shrinking from the fight. Shamed, Alexander offers to engage Menelaos in single combat, with the victor taking uncontested possession of Helen and the wealth she brought to Troy. As far as the wider conflict is concerned, Alexander envisions a negotiated settlement: once the duel is resolved, the disputants' respective communities will establish philotês through oaths, and the Argives

\footnotetext{
${ }^{5}$ Alonso 2007, 212.
} 
will return peacefully to their homeland (3.73-75). Hektor steps forward to present Alexander' offer, and Menelaos, accepting, calls for sacrificial victims so that the leaders of the armies may swear an oath to abide by the terms of the treaty. These ritual preparations represent the first concrete step toward a reconfiguration of the relationship between the warring parties. The assembled soldiers of both sides respond with collective sentiments of joy and hope:

So he spoke, and both the Achaeans and the Trojans rejoiced, hoping for an end to toilsome war. ${ }^{6}$

\subsection{1-12}

The fact that Trojans and Achaeans respond as a group, as the collective subject of the verb, marks an important moment of social adjustment, an incremental step toward the fusion of discrete entities.

The full significance of this response emerges more clearly when viewed against the background of the set of formulas the Iliad employs to describe the responses of audiences in deliberative contexts. A superficial reading of the collective reaction of Achaeans and Trojans might register it simply as the mechanical consequence of a unique situation, namely, the formulation of a proposal addressed jointly to both sides. Such a reading, however, goes against the grain of a textual strategy aimed at constructing broad distinctions between Greek and Trojan collective behaviors. ${ }^{7}$ Nowhere is this strategy more evident than in the system of formulas for audience response in scenes of collective decision-making, what might be called the poem's "grammar of reception." 8 The Iliad employs a fairly restricted set of such formulas. Generally speaking, Iliadic audiences

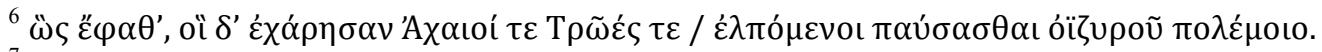

${ }^{7}$ On the ways in which the Iliad distinguishes between the Greek and Trojan communities, particularly with regard to speech, see Mackie 1996.

${ }^{8}$ This grammar is the subject of my ongoing research, building on the work undertaken in Elmer 2005.
} 
display one of five reactions to deliberative proposals, expressed in the following five ways (with variations) ${ }^{9}$ :

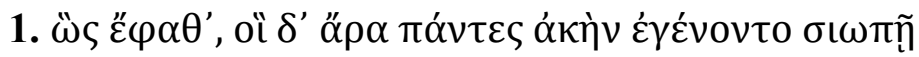

He spoke thus, and they were all silent

$(3.95,7.398,8.28,9.29$, etc. $)$

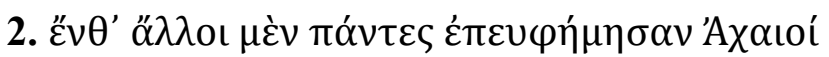

Thereupon all the other Achaeans expressed approval $(1.22,1.376)$

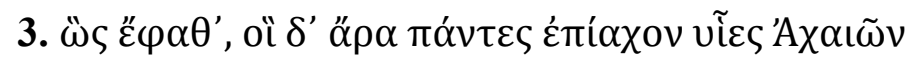

He spoke thus, and all the sons of the Achaeans shouted in response $(7.403,9.50$; variants at $2.333,2.394)$

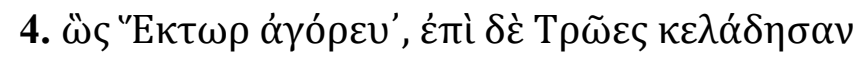

Hector spoke thus, and the Trojans roared in response $(8.542,18.310)$

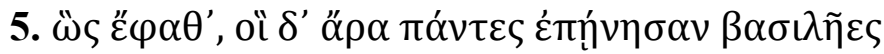

He spoke thus, and all the kings approved

(7.344, 9.710; variants at 3.461, 23.539; cf. 2.335, 4.29, 4.380, $16.443,18.312,22.181)$

The essential thing to note about this formulaic system is the rigor with which it distinguishes between the behaviors of different communities. The first and last of these responses occur among both Greek and Trojan audiences, but the other three are strictly limited to one or the other group. Moreover, the single instance in which a Trojan audience responds with a version of the fifth reaction (18.312) acquires its significance

\footnotetext{
${ }^{9}$ This list omits another formula frequently used to indicate that a proposal has been accepted: $\ddot{\iota} \varsigma \varepsilon \tilde{\varphi} \varphi \alpha \theta^{\prime}$, oi

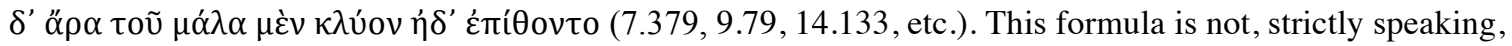
part of the "grammar of response," since it refers not to the reaction of the audience but merely to the efficacy of the proposal. Il. 2.142 and 9.173 both represent complex exceptions to the system, which I have elsewhere explained in terms of an emphasis, at moments of crisis, on social atomization, as opposed to the solidarity ideally operative in collective decision-making (Elmer 2005, 178-79 and 207-8).
} 
from the fact that this response is otherwise restricted to the Achaeans (and the Olympians): at a climactic moment in the narrative, the Trojans suddenly adopt a mode of collective decision-making more typical of their enemies, and opt for a course of action (camping on the battlefield to press their advantage in the morning) that leads ultimately to their demise.

Against this background, the peculiarity of the collective reaction of Achaeans and Trojans comes more clearly into view. The response formulas reviewed above focus on the presence or absence of a discernible sign of approval. In this case, however, the narrator refers simply to the affective disposition of the audience (joy mixed with hope), without specifying whether that disposition was expressed. The unambiguous disclosure of group sentiment is obviously essential to true collective deliberation. The narrator's lack of specificity on this occasion contributes to a certain ambiguity as to the nature of the proceedings. In spite of the obvious importance of a possible agreement to all those involved, we are entitled to wonder whether Alexander' proposal is a matter of group action or a purely private arrangement between himself and Menelaos. It has characteristics of both, but this is not, evidently, a scene of true collective decisionmaking; at least, the audience does not behave as though it were. The more important peculiarity for our purposes, however, concerns the simple fact that the same response is predicated simultaneously of two groups whose behaviors the Iliad is elsewhere at pains to distinguish. By violating the overall tendency of the poem's formulaic system, these lines offer a striking indication that the boundary separating the two sides is beginning to break down. 
The text specifies not only that Greeks and Trojans responded in the same way, but that they did so for the same reason: both groups were "hoping for an end to toilsome war." The prospect of a negotiated agreement therefore corresponds to the emergence of a unified sentiment among the warring parties. The poem seems to suggest that the very possibility of a treaty requires a coincidence of interests and attitudes. This in itself may not seem very significant: without a doubt, some common interest in seeking a resolution is always necessary to bring the parties to a conflict to the negotiating table. Be that as it may, the narrator goes to considerable lengths to stress this new community of spirit, tying it explicitly to the formal conclusion of the treaty. When Priam arrives from the city with the horkia, the sacrificial victims for the oath, Agamemnon pronounces the terms of the agreement. ${ }^{10}$ The horkia are then slaughtered and spondai poured. The sacrifice and libations formally inaugurate a new relationship between Greeks and Trojans, a relationship that is marked not only ritually, but also, once again, by a notable response on the part of the audience. If Menelaos' proposal of an oath was followed by the first suggestion of an emerging concord, the actual execution of the oath sacrifice results in a striking indication that Trojans and Greeks are now unified not only in sentiment but also in speech:

[Agamemnon] spoke, and he cut the necks of the lambs with the pitiless bronze.

And he laid them on the ground gasping and wanting for life, for the bronze had taken their strength. And drawing wine from the mixing-bowl with cups, they poured it out, and prayed to the eternal gods.

And someone of the Achaeans and Trojans was speaking thus:

\footnotetext{
${ }^{10}$ When Agamemnon reformulates the agreement, he makes an important addition to the terms: in the event of Alexander's defeat, the Trojans are to surrender not just Helen and her property, but also a "fitting" penalty "that will be remembered even among future generations" (3.286-87). Although there is no indication of any objection to Agamemnon's addendum, it undoubtedly makes it more difficult for the Trojans to accept his eventual judgment on the outcome of the duel (see below).
} 
"Most powerful and greatest Zeus, and you other immortal gods, whoever should first violate the oath-sacrifices, may their brains flow on the ground just like this wine, their own and their children's, and may their wives be taken by others."11 3.292-301

The prayer expressed in this collective manner - a prayer that, in itself, does not indicate anything more substantive than a common commitment to observing the terms of the treaty - is less striking than the fact that Trojans and Greeks here speak with a single voice, represented as the words of an anonymous "someone" (tis). The significance of this gesture must once again be elucidated with reference to the broader conventions of Homeric narrative.

There is, of course, nothing unusual in the introduction of such an anonymous statement into the narrative. Such passages, often called "tis-speeches" after the characteristic indefinite pronoun, or Chorreden in reference to their collective aspect, are widespread. ${ }^{12}$ There are 17 such speeches in the Iliad, nine of them transcribing, as here, what was actually said on a particular occasion, and 8 more describing the potential words of imagined speakers. The device is not, however, simply a way of indicating what isolated or scattered individuals said or might have said, as though the Homeric narrator were a reporter stopping passers-by for a "man-on-the-street" perspective. On the contrary, speeches attributed to an anonymous tis are the way the Homeric narrator introduces a collective sentiment, a view that characterizes a distinct social group. In the Odyssey, for example, the attitudes and intentions of the suitors are several times

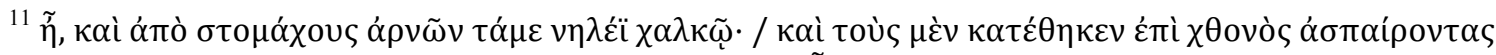

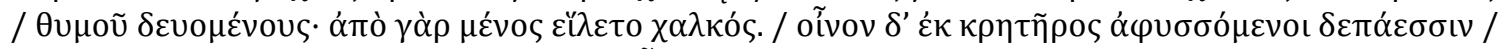

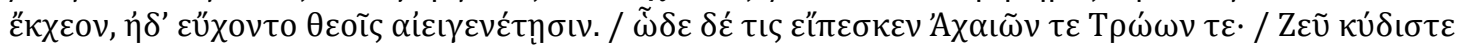

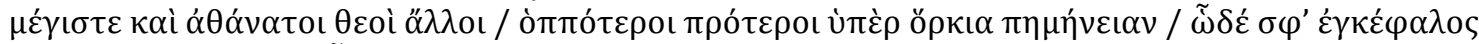

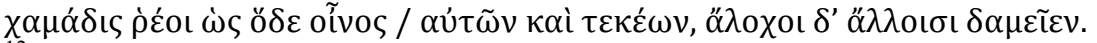

${ }^{12}$ For recent scholarship on Homeric tis-speeches, see Wilson 1979, de Jong 1987, and Létoublon 1995. For the term Chorreden, see Hentze 1905. De Jong 1987, 71 emphasizes that, in the passage quoted above, Greeks and Trojans are "presented as a collective" (emphasis original).
} 
registered by means of such speeches; the discreditable sentiments expressed on these occasions are clearly meant to reflect on the suitors as a group. ${ }^{13}$ Moreover, the formulation of a collective attitude in a tis-speech highlights the cohesion of the group to which it is ascribed. It thereby comes to function as a narrative index of social solidarity. The clearest example of this technique is in the Achaean assembly of Book 2. After the near-disintegration of the army, Odysseus manages to restore order. A crucial step in his reconstitution of the army as a cohesive group is the forceful silencing of Thersites; this scene is capped by the words of the pletthus, the mass of soldiers, as expressed in an anonymous tis-speech:

And [the Achaeans], though distressed, laughed at him with pleasure. And thus someone was saying, looking at another near by:

"Well! Truly Odysseus has done countless good things as author of good counsels and leader in war; but now this is the best thing he has done among the Argives, in that he has stopped that wordy slanderer from speaking in public. His over-proud heart will surely not stir him again to antagonize kings with words of blame."

$2.270-77$

Speeches such as this one are evidently meant to express some kind of pervasive social force, a collective feeling that defines or even constructs a group. ${ }^{15}$ The attitude of the Achaean plêthus towards Thersites is one of the chief indicators in this scene that a social bond has been restored.

The anonymous speech that caps the oath-sacrifice in Book 3 serves the same function. The words spoken in common by Trojans and Achaeans make manifest the

\footnotetext{
${ }^{13}$ See, for example, $O d .2 .324-36,4.769-71$.

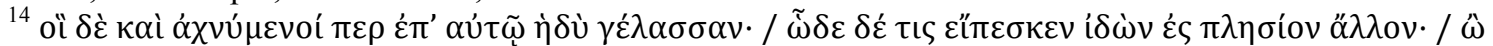

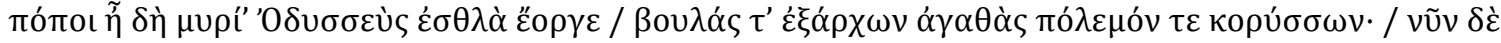

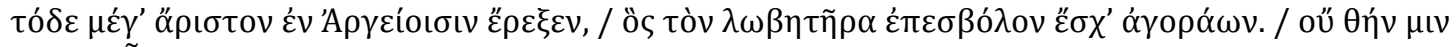

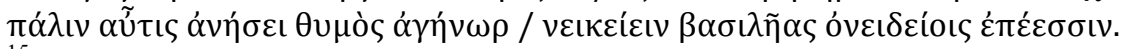

${ }^{15}$ Cf. Létoublon 1995, 2.
} 
social bond the treaty has created (or perhaps the bond that such a treaty requires). Not coincidentally, this manifestation of solidarity occurs at the very moment of sacrifice, the moment when the wine is poured out on the ground. ${ }^{16}$ The conjunction here of sacrifice and collective utterance recalls the importance of sacrifice generally in Homer as a socially meaningful act. Sacrificial meals frequently mark the establishment or reaffirmation of connections between members of a group. ${ }^{17}$ But this is not a sacrificial meal: as in the case of the Iliad's other oath-sacrifice (19.266-68), the victims are evidently disposed of without being consumed. The social significance of this sacrifice derives strictly from its relation to the treaty, from the fact that it is the ritual complement to the oath pronounced by Agamemnon.

The words of the anonymous representative of the "Achaeans and Trojans" likewise stand in a complementary relationship to the oath. In addition to its typological function as an expression of the solidarity of a newly-constituted group, the $t i s$-speech is also the event that collectivizes the obligations imposed by the treaty. It is essential to recognize the public force of this utterance, which is not simply, as Irene de Jong has it, "a private prayer of Greek and Trojan soldiers" that "forms an interesting contrast to Agamemnon's official prayer." 18 The contrast, if there is one, is simply a matter of the discrete role played by this speech in the overall logic of the treaty ritual. Agamemnon's oath formulates the terms of the treaty, but it is the anonymous prayer of Achaeans and

\footnotetext{
${ }^{16}$ Cf. de Jong 1987, 70 .

${ }^{17}$ Cf. Seaford 1994, 42-53. Notable examples are the sacrifice that concludes Iliad Book 1, the meal Agamemnon serves to the gerontes at Il. 9.90, the meal shared by Achilles and Priam in Book 24, and the meal on Laertes' farm in $O d$. 24. Conversely, irregular meals or sacrifices indicate some disruption of the community. For example, when Achilles is visited by the Embassy, he serves the meat of animals that have already been slaughtered (Patroklos burns thuêlai, but the sacrificial killing is omitted: 9.206-21). The many scenes depicting the feasting of the Suitors are also part of the portrayal of their group as a dysfunctional community.

${ }^{18}$ De Jong 1987, 70 (emphasis original). Hentze 1905, 257 and Bergold 1977, 102 both emphasize the connection between the anonymous prayer and the oath ceremony.
} 
Trojans that stipulates the sanction for violating it, and thus creates a collective obligation to uphold it. ${ }^{19}$ There is no break or discontinuity between the oath ceremony and the anonymous speech of those who witness it; on the contrary, the latter is a vital part of the former.

Comparison with the inscriptional records of historical treaties helps to clarify this point. The organization of the Iliadic passage in fact bears a striking resemblance to what we find in many treaty-inscriptions, in which the terms of the treaty are regularly followed by the text of the oaths to be sworn by representatives of the communities in question. Notably, the oaths are often composed in the first-person singular, as in the case of a $4^{\text {th }}$-century summakhia treaty, from which I excerpt below:

Alliance of the Corcyreans and Athenians for all time: if anyone should attack the land or the people of the Corcyreans, the Athenians are to come to their aid in full strength, according to the demands of the Corcyreans, as they are able. And if anyone should attack the people or the land of the Athenians either by land or by sea, the Corcyreans are to come to their aid in full strength, as they are able, according to the demands of the Athenians.... The oath: "I will aid the people of the Corcyreans in full strength, as I am able, if anyone should attack the land of the Corcyreans either by land or by sea, according to the demands of the Corcyreans. ... These things are true by Zeus and Apollo and Demeter; if I keep my oath, may I enjoy many good things, and if not, the opposite." "I will aid the people of the Athenians in full strength as I am able, if anyone attacks the land of the Athenians either by land or by sea, according to the demands of the Athenians.... These things are true by Zeus and Apollo and Demeter; if I keep my oath, may I enjoy many good things, and if not, the opposite. ${ }^{20}$

\footnotetext{
${ }^{19}$ Cf.19.264-65 (with Bergold 1977, 102): when swearing, by means of a similar oath sacrifice, that he has not touched Briseis, Agamemnon concludes by stipulating the sanction for perjury. The statement of the terms of the oath and the stipulation of the sanction here occur in the same prayer; in Book 3, these two components are distributed between Agamemnon and his audience.

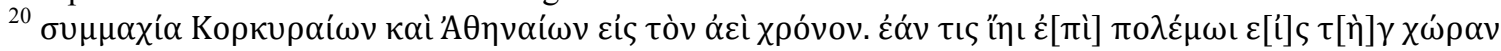

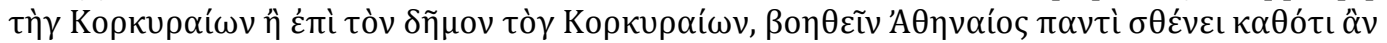

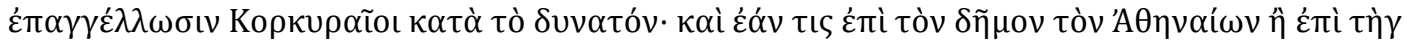

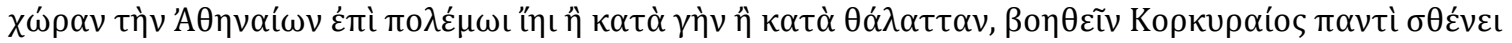

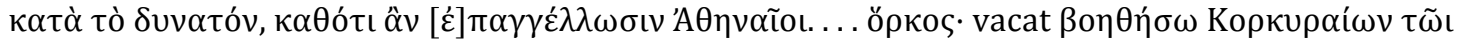

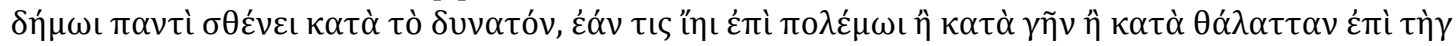

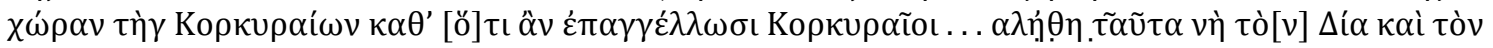




\section{IG II $^{2} 97(375$ BCE)}

The oaths recorded in this inscription represent the words of individuals who are binding themselves to abide by an agreement made between groups. As in the Iliad, the sanction

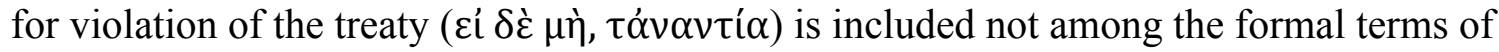
the agreement, but as a prayer pronounced by representatives of the communities in question. The resolution of the collective obligations of the group into the individual obligations of its members is one of the more curious and persistent features of Greek diplomacy. ${ }^{21}$ It is evidently the reflex of tendencies rooted deeply enough in Greek culture to find expression also in the Iliad, where the collective force of the sanction is formulated in the speech of a singular tis. There is a continuity of mindset underlying these two representations of collective commitments. The practices reflected in the treaty oaths provide a valuable context for understanding not only the logic of the treaty scene in Iliad 3, but also the more general Homeric tendency to delineate the attitudes and investments of a community as a whole in terms of the superficially singular pronouncement of an anonymous tis.

There is, however, an important discrepancy between the oaths transcribed in treaty inscriptions and the collective prayer of Greeks and Trojans. The inscriptions record different oaths for the citizens of each state; the differences might be substantial, with different clauses and provisions prescribed for each side, but at the very least the

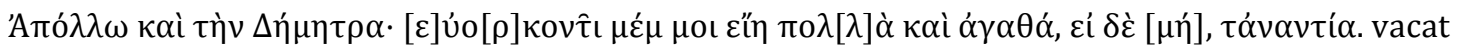

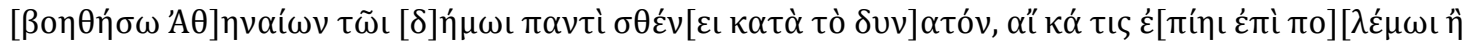

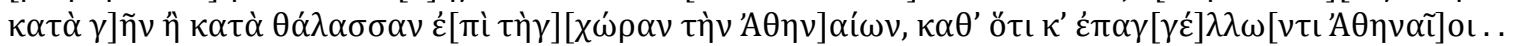
$. \alpha \dot{\alpha} \lambda \eta \theta \tilde{\eta} \delta \grave{\varepsilon} \tau \alpha \tilde{u}] \tau \alpha v \alpha[\grave{i} \tau]$ òv $\Delta \dot{c} \alpha[\kappa \alpha] \grave{i}$

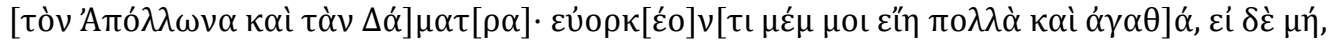
$[\tau \dot{\alpha}][v \alpha v \tau i ́ \alpha]$.

${ }^{21}$ Cf. Bolmarcich 2007, 26 and Plescia 1970, 60. The individuals swearing the oaths might sometimes be the officials responsible for the excecution of the treaty, and sometimes significantly larger groups.
} 
name of one state must be substituted for the other, depending on the party in question. ${ }^{22}$

In the case of the treaty quoted above, the text even transcribes dialectal differences, faithfully reproducing certain Doricisms typical of the local speech of Corcyra, a Corinthian colony. ${ }^{23}$ In the Iliad, on the other hand, Achaeans and Trojans utter the same prayer. The disparity is telling: while the treaties literally inscribe the distinction between communities by distinguishing the words spoken by their respective representatives, the narrative of the Iliad works to elide this distinction by constructing a single community of speech. The negotiation of an agreement to end the Trojan conflict is represented not, as in the inscriptions, as a matter of the relationship between groups whose independent identities are rigorously maintained, but as the merging of groups into a new supercommunity, centered around common interests that can be expressed in words available to one and all.

Shortly after the oath sacrifice and the accompanying collective prayer, a second tis-speech reinforces the connection between the negotiation of a truce and the creation of a temporary community, united in sentiment and speech. As Hector and Odysseus cast lots to determine whether Alexander or Menelaos will have the first spear-cast, the narrator reports another prayer uttered by both sides in common:

And someone of the Achaeans and Trojans was speaking thus: "Father Zeus, ruling from Ida, most powerful and greatest, whoever it was that brought these trials to both peoples,

\footnotetext{
${ }^{22}$ For an example of substantial differences, see IG $\mathrm{i}^{3} 76$, a treaty between Athens and the Bottiaioi dated to 422. The differences in this case are doubtless due to an asymmetrical power relationship. Thucydides 5.47 gives a single oath for both parties in the case of a treaty between Athens and the Argives, Mantineans, and Eleans, but includes also the stipulation that "they shall each swear the oath that is most binding in their own country."

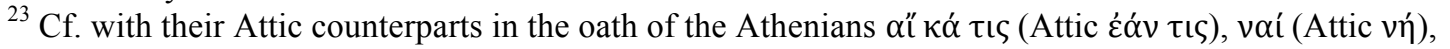

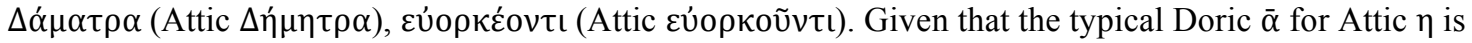
only inconsistently observed, it is tempting to think that the composer of the inscription has been particularly scrupulous in rendering the names of the gods called to witness the oath ( $\Delta \alpha \dot{\alpha} \mu \alpha \tau \alpha$ vs.

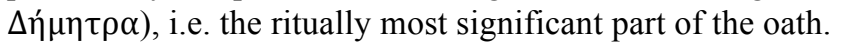


let him perish and enter the house of Hades, but let us have friendship and steadfast oaths." 24

The openness with which the question of responsibility is posed emphasizes the recentering of Greek and Trojan relations around a kind of common denominator of shared interest. In spite of the general acknowledgement of Alexander's guilt elsewhere in the poem, even among his own countrymen, this prayer remains open to the possibility that Menelaos might bear responsibility, a point of view that seems patently calculated for universal acceptability. ${ }^{25}$

The duel ends inconclusively when Aphrodite spirits Alexander away from the battlefield and saves him from imminent death. The ambiguous outcome, unforeseen by the terms of the agreement, initiates a period of uncertainty, but the treaty still holds, for a time. And so long as the treaty holds—-so long, that is, as the Trojans and Achaeans enjoy a relationship that is not simply one of hostility—so too does their ability to speak with a single voice. Book 4 opens with a brief discussion among the gods about whether or not to permit a negotiated conclusion to the war (I will have more to say about this scene in a moment). They resolve to initiate a new phase of fighting, but when Athena descends from Olympus to implement their decision, a third and final corporate utterance uniting Greeks and Trojans signals that, as yet, the truce holding together the fragile GrecoTrojan community still stands:

Just like a star that the son of wily Kronos sends, as a sign for sailors or for a broad host of fighting men, shining, and trailing many sparksjust so did Pallas Athena dash to the earth,

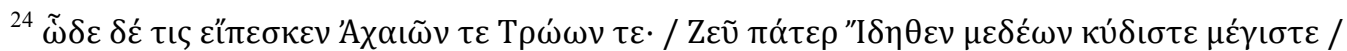

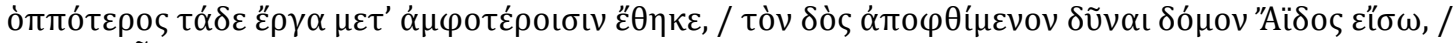

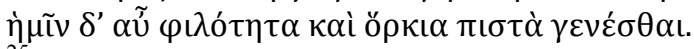

${ }^{25} \mathrm{Cf}$. the comments of Kirk 1985 on 1. 321.
} 
and she lept into the middle; and wonder held those looking on, horse-taming Trojans and well-greaved Achaeans.

And thus someone was saying, looking at another close by:

"Surely we will again have evil war and terrible slaughter-

or Zeus is establishing friendship among both peoples,

Zeus who is the steward of war for men."

Thus someone of the Achaeans and Trojans was saying. ${ }^{26}$

4.75-85

Even as they contemplate the possible dissolution of the treaty that binds them, the two groups still manage to speak as one; the imminent shift that will redefine their relationship has not yet been realized.

These are, however, the last words pronounced in a collective voice. They provide a final statement of the common perspective embodied in the Greek and Trojan supercommunity, and they are situated in such a way as to provide a striking point of contrast for the moment at which the community is in fact dissolved. After her meteoric arrival at Troy, Athena instigates Pandaros to shoot an arrow at Menelaos. Menelaos is struck, but the wound proves to be fatal only to the delicate peace agreement, which is effectively ended by this breach of the truce. Agamemnon marks its demise rhetorically in his response to the calamity. In voicing his distress at Trojan perfidy and the near loss of his brother, he uses a potential tis-speech to construct a Trojan voice that is unambiguously hostile:

"And one of the haughty Trojans will speak thus, leaping on the tomb of glorious Menelaos:

'May Agamemnon vent his anger on all this way, as even now he brought here a host of Achaeans in vain, and he went home again to his fatherland

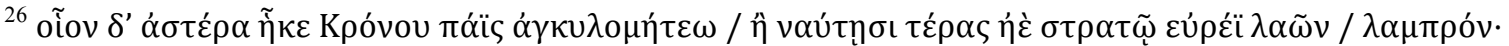

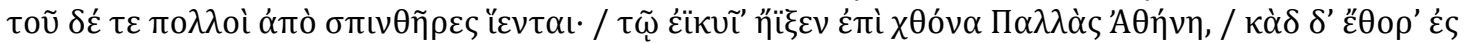

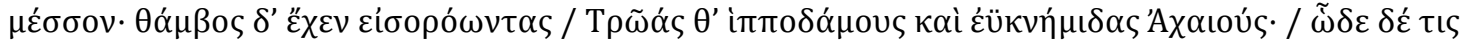

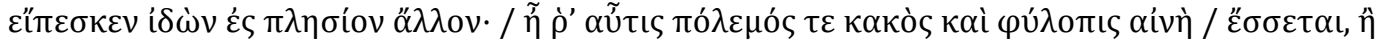

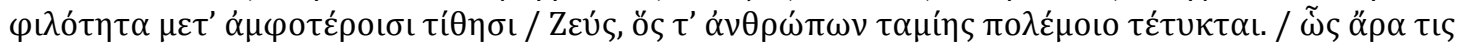

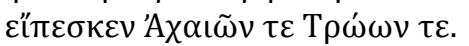


with empty ships, having left behind good Menelaos.'

Thus will someone speak; then let the wide earth open for me."27

$$
\text { 4.176-82 }
$$

This anonymous voice, projected onto an exclusively Trojan landscape devoid of a living Achaean presence, could not be more different from the voices that have populated the scene up to this point. Agamemnon seems almost deliberately to be marking the end of the community of speech by re-imagining Trojan sentiment as irreconcilably inimical to the Greeks. His imagined utterance reinstates the divide that separates the two communities.

We do not encounter the anonymous speech device again until the conclusion of the duel between Hektor and Ajax in Book 7, a passage that, incidentally, also offers the poem's only other instance of a speech attributed jointly to both Greeks and Trojans. Hektor imagines a remark that will be spoken by warriors on both sides when they observe that he and Ajax have exchanged gifts (7.299-302). This remark consists of an explicit acknowledgment of the philotês of which the gifts themselves are a material token. Although we cannot speak here of a proper community — this philotês binds only Hektor and Ajax, and evidently only to a limited extent, since they will later take up arms against each other again - nevertheless we again observe a correlation between the possibility of a common utterance and the existence of a social bond that traverses the gap between Trojans and Achaeans.

There is clearly a connection between Hektor's hypothetical speech of Achaeans and Trojans, marking the relatively amicable conclusion of his duel, and the imagined

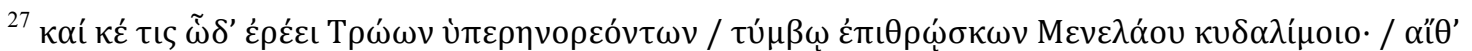

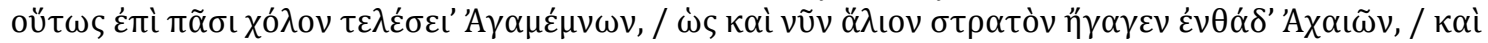

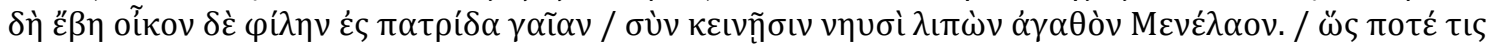

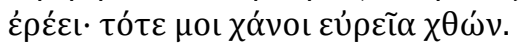


speech with which Agamemnon punctuates the disastrous results of the previous one. ${ }^{28}$ Nevertheless, the Trojan boast constructed by Agamemnon stands in a much closer relationship to the other anonymous speeches in Books 3 and 4. It brings to a close a remarkably dense sequence of such speeches that, as we have seen, coincides precisely with the period of the truce. Four of the Iliad's 17 tis-speeches, or nearly one quarter, cluster around Book 3 and the beginning of Book 4. The concentrated exploitation of this technique bears all the hallmarks of a deliberate strategy designed to set off the period of the truce as a time when the differences between the Greek and Trojan communities are temporarily bridged. ${ }^{29}$ To the extent that the anonymous tis-speech implies a cohesive group partaking of a common sentiment, this strategy insists on the correlation of the existence of an agreement with the existence of a single community to which the parties to the agreement belong. That is, in terms of the Iliad's conceptual apparatus, an agreement is thought of not as something between groups but as something that unites the members of a single group. The Iliad's word for the treaty is philotês; and philotês is philotês, whether it binds Achaeans and Trojans, Hector and Ajax, or the Achaeans as a whole.

\section{Finding common ground}

The use of anonymous speeches to suggest the construction of a Greek and Trojan super-community is complemented by a parallel strategy focusing not on the behavior of

\footnotetext{
${ }^{28}$ There are a number of connections between the duels in Books 3 and 7, on which see Kirk 1978. The relationship between these scenes cannot, however, be adequately appreciated in terms of Kirk's scheme of primary use and secondary reworking or imitation.

${ }^{29}$ With this technique, contrast the juxtaposition of two opposed tis-speeches, one attributed to "someone of the Achaeans," the other to "someone of the Trojans," at 17.414-22. These juxtaposed speeches express the hardening of the battle lines in the conflict over Patroklos' corpse.
} 
the constituents but on their spatial organization. Corresponding to the emergence of a verbal discourse shared by Trojans and Achaeans is the establishment of a common space, a center or mes(s)on around which the two groups can arrange themselves. The formal act of fixing this central space - which also serves as the field of battle for Menelaos and Alexander (cf. 3.341) — is performed by Hektor and Odysseus as they measure off the dueling ground. ${ }^{30}$ The meson appears, however, to be already identifiable from the moment that Hektor steps forward to propose a negotiated settlement ( $\varepsilon^{\prime} \varsigma$

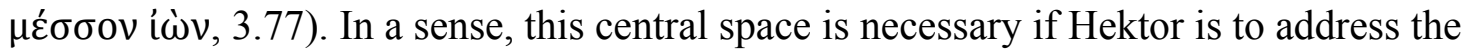
Greeks and Trojans as a whole, and if his words are to have their intended effect of binding the two sides in agreement. Marcel Detienne has demonstrated the importance archaic Greek thought ascribes to the meson as a point of orientation for the community, as the locus for the definition of common property and the common good, and, finally, as the foundation for politically efficacious speech. ${ }^{31}$ Speech oriented toward the establishment or maintenance of the community must proceed from the meson. A middle point appears to be necessary in Greek thinking for the conceptualization of a community at any level: the oikos has its hearth, the polis its agora, and even supra-polis associations such as the confederated cities of Lesbos organize themselves around a center. ${ }^{32}$

Accordingly, the ability of Greeks and Trojans to constitute themselves as a single group with common interests expressed in common words goes hand in hand with the existence of such a space in which those words can be spoken, a space belonging equally to both sides.

\footnotetext{
${ }^{30}$ Odysseus' involvement in this procedure is not without significance: his own ship is at the center of the Achaean camp (8.223), which is an index of his role as a proponent of solidarity among the Achaeans.

${ }^{31}$ Detienne 1965 and 1996 (1967), 90-102, building on Vernant 1982 (1962) and Lévêque and VidalNaquet 1996 (1964).

${ }^{32}$ See Detienne 1996, 101 on Messon, the centrally-located, federal sanctuary on Lesbos.
} 
From this perspective, it is no surprise to find a consistent link between the communal utterances of Books 3 and 4 and the spatial center around which the events of the episode are organized. Each of the tis-speeches I have examined is connected to some event happening at the meson. In the case of the collective prayer that initiates the series, that event is the oath-sacrifice, which is situated specifically at the center (3.266). The second prayer follows immediately on the delimitation of the central dueling ground and the drawing of lots that takes place there. And the third and final joint speech responds directly to Athena's divine manifestation as she leaps "into the middle" of the Trojans and Achaeans (4.79). In each case, events at the center provide the referent for an utterance that indexes the social bond uniting Greeks and Trojans. This center is, therefore, an indispensible component of the conceptual and narrative apparatus that serves to delineate the transitory Greco-Trojan community: without it there would be no collective utterance, and no space within which such an utterance could emerge. Moreover, when that community ultimately dissolves, its disintegration must be marked spatially as well as in speech. Just as Agamemnon asserts the demise of the community of speech by substituting a hostile Trojan utterance for a collective voice, so the narrator seems compelled to re-inflect the meson not as a space of convergence around common interests but as one of difference and conflict. After Menelaos has been wounded but before the general mêlée begins, Eris, personified strife, sets neikos homoiion, conflict common to all, "in the middle":

Ares stirred the one side, and grey-eyed Athena the other, and Fear and Flight and Strife, full of insatiable longing, the sister and companion of man-slaying Ares, who is small when she first takes up arms, but thereafter walks the earth with her head fixed in the heavens; and at that time she set in their midst conflict shared by all, 
and she went through the throng increasing the groans of men.

But when they came together, gathering in one place,

they threw against each other their shields, their spears, and men's fury... ${ }^{33}$

4.439-47

As the two armies advance into the space that divides them, all they have in common is

their hostility. ${ }^{34}$

\section{The limits of community}

The discussion thus far has focused on the two interlocking techniques by means of which the Iliad represents the treaty of Books 3 and 4 as a convergence of two hostile groups and their reconstitution as a single super-community united in space, speech, and sentiment. The Iliadic tradition seems unwilling or unable to conceive of an agreement as a bond between distinct groups: the very notion of a bond appears, in this mentality, to imply the existence of a single group. The question remains, how viable is that bond and the community it implies in the case of the Greeks and Trojans? The treaty is ultimately voided as a result of divine intervention. Does that mean that it might have remained in force in the absence of interference? There are indications in the text of a profound skepticism about such a possibility. In particular, the end of Book 3 and the transition to Book 4 are structured in such a way as to suggest that, in spite of their new-found ability to organize themselves as a cohesive group, the Trojans and Achaeans still face severe limitations on their ability to maintain the integrity of their association in circumstances that are less than fully straightforward.

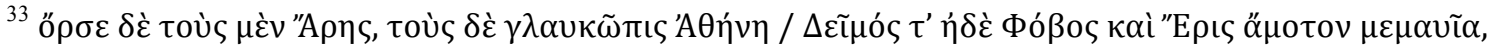

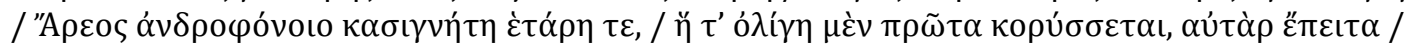

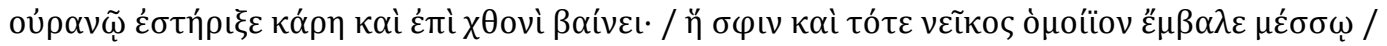

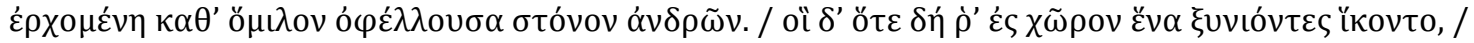

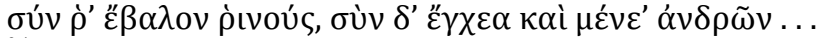

${ }^{34}$ Nenci 1981, 153 emphasizes the potential ambiguity of the meson, which can be a space either of cooperation or of conflict.
} 
At the end of Book 3, the duel has come to an ambiguous conclusion with the disappearance of Alexander. Menelaos has succeeded in despoiling his opponent of at least part of his armor (his helmet), and the narrator makes him the clear moral victor, stating that "he would have won untold kudos" if Aphrodite had not taken action (3.373). On the basis, presumably, of Menalaos' superior performance and the fact that Alexander is no longer anywhere to be seen, Agamemnon declares that Menealos' victory is

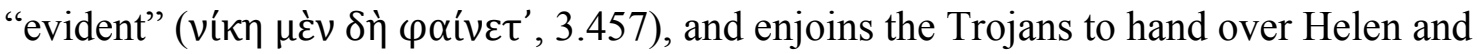
the penalty he had stipulated in the case of Alexander's defeat. Agamemnon's interpretation lays claim to being an objective assessment of the available evidence- the "evidential" particle dê signals that his statement is based on direct perceptions that he assumes to be available to his audience as well ${ }^{35}$ — but it is, nevertheless, tendentious. The treaty had defined victory with respect to the killing of one party by the other

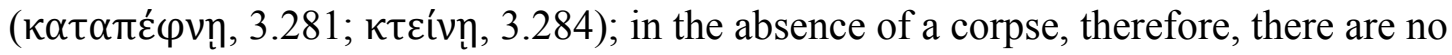
grounds for determining the victor. As it stands, the duel has resulted in a situation unforeseen by the original agreement, and undecidable on its terms. Agamemnon's judgment represents an extension of the treaty's provisions to cover a situation that lies beyond their scope, an extension that is perhaps not unjustified, but certainly motivated by self-interest.

It is not surprising, then, that only a portion of Agamemnon's audience approves his verdict - the portion that stands most to gain by such a result. Book 3 ends with the notice that Agamemnon's pronouncement receives approval, but it is an approval that is

\footnotetext{
${ }^{35}$ On dê as a "marker of evidentiality," see Bakker 1997, 75: "the dê clause, being directed to an addressee, signals that the speaker assumes that the hearer is capable of witnessing the same evidence." For certain historical audiences of the Iliad, Alexander's helmet was still available as evidence for Menelaos' mastery in the duel: the Lindos chronicle records that the helmet was on display in Athena's great Rhodian temple (see Higbie 2003, 87-88 and 223-26).
} 


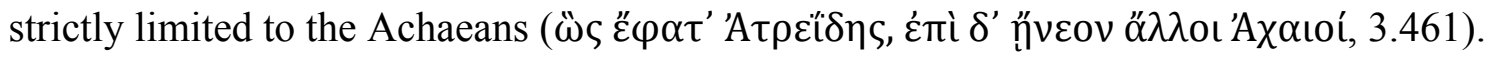
Nothing is said about any response on the part of the Trojans. The significance of the Achaean reaction must again be elucidated with reference to the "grammar of response" outlined above. The approval of the Achaeans is expressed with a variant of the fifth of the Iliad's response formulas, which is characterized by the verb epainein. This formula represents the most decisive form of approval that an Iliadic audience can bestow on a deliberative proposal. It signals not just support for a speaker's remarks, but the effective ratification of them. Louis Gernet detected in the verb epainein the idea of a "quasijuridical efficaciousness," and, as a rule, any proposal that meets with epainos is immediately put into effect. ${ }^{36}$ Here, however, this general rule runs up against an interesting complication. The notionally efficacious response of a single constituency is embedded in a context that stresses an expanded notion of community involving commitment from both sides. In such a context, what value can be ascribed to the support, no matter how decisive, of only one of the concerned groups? The text has arrived at a kind of aporia, an impasse in which a rule of the poem's formulaic grammar is pitted against a more localized trend. The Achaeans may be able to express a unified will, but they are only one part of a larger group. That larger group, in the meantime, seems unable to formulate a collective response to the situation. The duel and its aftermath thus expose the limits of Greco-Trojan solidarity and suggest a skepticism about the possibility of establishing a functioning super-community.

It might be thought that the problem lies not with the project of creating an expanded community, but with the ambiguous conclusion of the duel, a situation

\footnotetext{
${ }^{36}$ Gernet 1948, 186. Note that the noun epainos does not occur in the Homeric poems; I use it here as convenient shorthand for the uniquely decisive response signaled by epainein.
} 
problematic enough to create difficulties for any community, no matter how cohesive. Such an understanding, however, disregards the fact that the cohesiveness of a community cannot be judged in the absence of some test of its solidarity. The strength of a social bond remains only a potentiality until it is subjected to stress. The Iliad repeatedly uses complex or ambiguous situations-Agamemnon's insincere proposal to decamp in Book 2, for instance, or the challenge of maintaining solidarity in spite of the absence of Achilles - to examine the sturdiness of Achaean society. The present occasion is no different: the point of the episode is that the Greco-Trojan community has been tested, and found wanting.

The failure of Greeks and Trojans to constitute themselves as a fully cohesive group is highlighted by juxtaposition with the divine community, which successfully negotiates a response to the same uncertain situation. With the articulation of an approval limited to the Achaeans, the narrative reaches a dead end; the discussion on the plain of Troy is abandoned with the last line of Book 3 , and the scene switches suddenly to Olympus at the start of Book 4. There, the gods take up the issue of how to resolve the ambiguities of the duel, even as the force of a limited and partial epainos is left an open question. It is as if, having raised the specter of an irreconcilable conflict at the heart of the Greco-Trojan accord, the narrator must have recourse to a whole and uncompromised social group in order to move the action forward. To be sure, the divine community is not a unified one. It includes entrenched partisans of both sides represented at Troy, whose differences seem at times no less insurmountable than those of their human protégés; in Book 20, the gods even take up arms against each other. Nevertheless, in spite of their differences, they are able to arrive at a course of coordinated action. Moreover, they do so 
by appealing to epainos, the very mechanism that indexes the limits of social coordination at Troy.

Zeus opens deliberations among the Olympians by seconding Agamemnon's judgment that victory lies with Menelaos (4.13). He invites the gods to consider whether they will, accordingly, allow a negotiated settlement to the war, or whether they will instead prompt a renewal of hostilities. He himself proposes that the war be settled according to the terms of the treaty (4.17-19). The narrator characterizes this suggestion as an insincere attempt to provoke Hera rather than a straightforward proposal (4.5-6), but the question of Zeus' sincerity is irrelevant to the subsequent debate, which exposes genuine differences between Zeus and his consort. ${ }^{37}$ Unable to contain her anger, Hera expresses her firm opposition to any negotiated outcome in terms of the withholding of epainos:

"Most terrible son of Kronos, what a speech you have spoken! How can you wish to render my labor vain and unfulfilled, and the sweat my toil has brought me; my horses have grown weary while I gathered the host, an evil thing for Priam and his children. Do what you like: but we other gods do not all approve." 38 4.25-29

This formulation of the restricted support Zeus' proposal would receive establishes an interesting parallel between the situation at Troy and the unfolding debate among the gods. Sincerely or not, Zeus has put forward the same proposition that Agamemnon presented to the assembled Achaeans and Trojans. In Agamemnon's case, that proposal

\footnotetext{
${ }^{37}$ As Kirk 1985, 331-32 notes, the narrator must do something to explain Zeus' proposal, since the prospect of peace would appear to run counter to the promise he has made to Thetis. Wilamowitz connected Zeus'

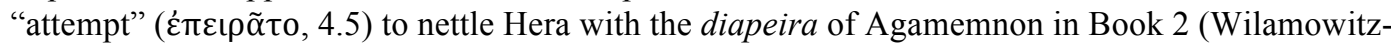

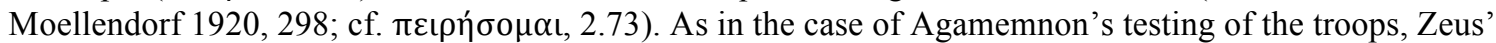
provocation leads ultimately to the confirmation of the traditional course of events on the part of the larger community.

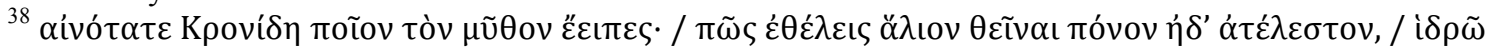
$\theta^{\prime}$ öv

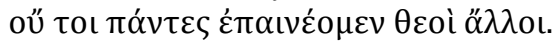


met with only limited approval. Hera predicts precisely the same result on Olympus: epainos for Zeus' proposed course of action will be only partial, attenuated, and therefore of questionable efficacy. She implies, menacingly, that the same impasse that now confounds the Trojans and Greeks might afflict the gods as well, with herself and Athena playing the role of dissenters. Her threat to withhold her consent places her in curious alignment with the Trojan position, an alignment that can only be considered ironic in light of her hunger for Troy's destruction.

In the event, however, the gods manage to avoid deadlock in a manner that points up simultaneously the strengths of the divine community and the corresponding weaknesses of the temporary coalition at Troy. Zeus expresses frustration at Hera's bitter

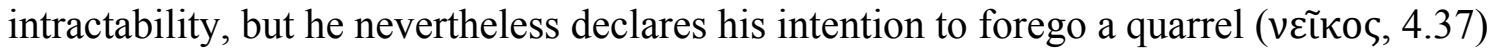
over Troy, now or in the future. He therefore relents, and agrees to Troy's destructionbut only on condition that Hera will reciprocally yield if and when Zeus wishes to destroy a city dear to her. For Hera, this balancing of present and future claims not only resolves the quarrel with her spouse, it also provides the foundation for widespread agreement among the gods as a group: "Let us yield to each other, I to you and you to me, and the

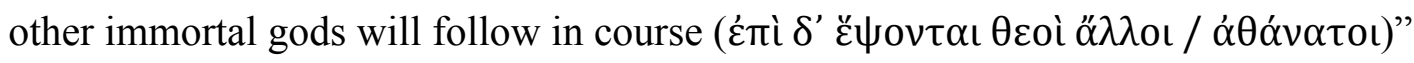

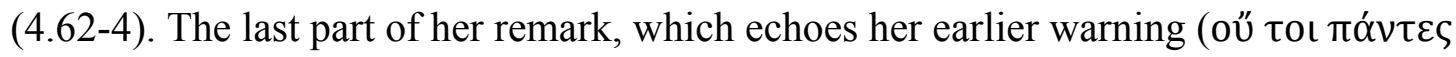

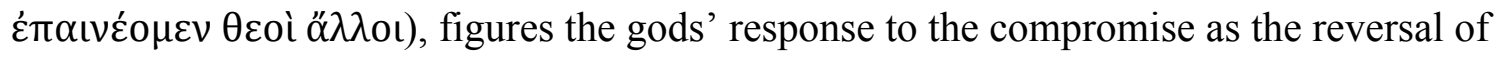
the threatened withholding of epainos for Zeus' initial proposal. Moreover, as Egon Flaig has argued, this vision of the equalization of distinct preferences, predicated as it is on a continuing context for interaction, corresponds to one of the basic requirements for 
consensus-based decision-making: the principle of "delayed return."39 This principle ensures that anyone who momentarily sacrifices his own interests in consenting to a decision will receive suitable compensation, or will have his interests protected, in future decisions. It requires that consenting individuals understand their losses and gains, first, as fundamentally comparable, and, second, as part of a continuum with both a past and a future - not as isolated, sui generis interests. That is to say, it requires that individuals understand themselves as members of a persistent community. These are the conditions that Zeus sets on his acquiescing to the destruction of Troy: his agreement is to be registered as part of an ongoing negotiation of preferences among the gods. While there is no positive statement of epainos to punctuate the transaction with Hera, the discussion nevertheless pivots on this crucial concept, and Zeus explicitly frames the negotiations in terms of the mechanisms of consensus.

The gods therefore succeed where the Greeks and Trojans fail: they manage to overcome significant differences and arrive at an executable course of action by exploiting the framework of epainos. The key to their success, and the crucial distinction that sets them apart from the Greco-Trojan community, is the existence of a persistent context of interaction extending beyond the present moment in time. Such a context is unavailable to the human actors attempting to settle the outcome of the duel. No matter how the war ends, once it is over the Achaeans' departure will put an end to the possibility of recuperating present loss with future gain. When Agamemnon uses the boast of an anonymous Trojan to encapsulate his vision of an Achaean defeat, he imagines a landscape totally devoid of any Achaean presence apart from the bones of his

\footnotetext{
${ }^{39}$ See Flaig 1993, 141 and 1994, 16 and 25 for "das Prinzip der vertagten Gegenleistung”; cf. Graham 1984,105 on delayed return as the "mystique" of democracy.
} 
brother Menelaos (4.172-75). The immobility of those bones in a funeral mound that will serve eternally as the locus for the Trojans' boastful exultation expresses the petrification of the Trojan-Greek relationship in a state of permanent disadvantage to the Achaean side. By the same token, the negotiated settlement proposed by Agamemnon will likewise perpetuate a permanently asymmetrical relationship, formulated in terms of a "timê that will be remembered even among future generations" $(3.287=3.460)$. The decision to bring about such a relationship simply cannot be made communally, that is, through a consensus involving both sides, since the result would effectively foreclose the contextual field on which consensus rests.

The Achaeans and Trojans therefore revert to a relationship of hostility, even as their respective partisans on Olympus manage (for a time) to reassert their collective identity. What is remarkable about this picture is that the alternative to hostility is not friendship, conceived as a relationship between two distinct, autonomous groups, but the construction of a larger community of interests that subsumes distinct groups. Such a community persists only so long as the framework that sustains its internal relationships remains functional.

No doubt, to assert that a community survives only so long as its facilitating framework amounts to a tautology. It is a useful tautology, however, insofar as it grounds the idea of community in a pragmatic context of interaction — rather than, say, in the more abstract concept of "identity." The Greco-Trojan community comes into being, in spite of obvious differences at the level of identity, because of the availability of such a context. By the same token, even a shared identity may not be sufficient to guarantee the viability of a community in the absence of opportunities for the ongoing negotiation of interests. 
That is to say, the breakdown of the Greco-Trojan community is not necessarily an idiosyncratic development, tied to the peculiar nature of this association of natural adversaries, but may well be indicative of the inherent weaknesses of any collective entity. The flipside of the fluidity that allows even enemies to reconstitute themselves as a single group is an instability even in apparently secure associations.

This instability is a major theme of the Iliad, which, for all its interest in the conflict between the Greeks and the Trojans, is equally or even more interested in the conflicts that divide the Achaeans themselves. Their internal disputes (also over a woman, in the first instance) are not qualitatively different from those that drive the war. And as the Achaeans seek to restore some measure of solidarity in the later books of the poem, they do so under the shadow of the failed truce of Books 3 and 4. In fact, the formal reconciliation between Achilles and Agamemnon unfolds almost as a replay of the earlier scene. When Achilles declares his readiness to put an end to his anger, the assembled Achaeans experience the same kharis they felt, along with the Trojans, in Book 3:

So he spoke, and the well-greaved Achaeans rejoiced as the great-hearted son of Peleus renounced his anger. ${ }^{40}$ 19.74-75

As in Book 3, the use of a formula that does not belong to the normal "grammar of reception" signals the ambiguous nature of a rapprochement that is fundamentally private, but fraught with consequences for the community. The echo of the truce is

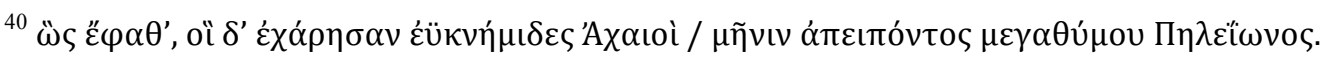


reinforced a short while later, when Agamemnon summons horkia and conducts an oathsacrifice, the only other example of an oath-sacrifice in the Iliad (19.250-68). ${ }^{41}$

What are we to make of the convergences between these two scenes? Certainly they emphasize the extent to which Achilles has been alienated from his confederates: his reconciliation with Agamemnon is conducted as though it were a treaty between battlefield foes. The specter of the failed truce, however, also suggests that the restoration of Achaean solidarity remains precarious, and invites us to wonder just how long the Achaeans will be able to maintain their cohesiveness as a community. Achilles, it should be noted, does not partake of the meal that follows the sacrifice: he continues to be isolated, in important respects, from the community. ${ }^{42}$ And if the situation of the Achaean community at Troy is so precarious, what then will become of it after the end of the war, when Agamemnon's coalition breaks up and the various contingents return to their respective homes in Hellas? What will happen, that is, when the returning heroes enter history as the ancestors of the various local communities to which the poem's audiences belong? The failure of the Greco-Trojan experiment in community-building raises an anxiety about the prospect for collective solidarity in the absence of a persistent context of interaction. This anxiety points beyond the Iliad to the problems faced by the poem's real-life audiences, who inhabit a world in which such contexts must constantly be renegotiated.

\section{WORKS CITED}

\footnotetext{
${ }^{41}$ At 19.191, Agamemnon refers to this sacrifice as ǒ $\rho \kappa \iota \alpha ~ \pi ı \tau \tau \dot{\alpha}$, a formula that elsewhere refers only to a real or hypothetical agreement between Trojans and Achaeans.

${ }^{42}$ Seaford 1994, 159-60.
} 
Alonso, Victor. 2007. "War, Peace, and International Law in Ancient Greece." In War and Peace in the Ancient World, ed. K. A. Raaflaub. Malden, MA: Blackwell. Pp. 206-225.

Bakker, Egbert J. 1997. Poetry in Speech: Orality and Homeric Discourse. Ithaca, NY: Cornell University Press.

Bergold, Wolfgang. 1977. Der Zweikampf des Paris und Menelaos: Zu Ilias $\Gamma 1$ - $\Delta 222$. Bonn: Habelt.

Bolmarcich, Sarah. 2007. "Oaths in Greek International Relations." In Horkos: The Oath in Greek Society, eds. A. H. Sommerstein and J. Fletcher. Exeter, UK: Bristol Phoenix. Pp. 26-38.

Detienne, Marcel. 1996 (1967). The Masters of Truth in Archaic Greece. New York, NY: Zone.

---. 1965. "En Grèce archaïque: géométrie, politique et société." Annales: Économies, sociétés, civilisations 20(3): 425-41.

Elmer, David F. 2005. Homeric epaineô: The Politics of Reception and the Poetics of Consent. Ph.D. Thesis, Department of the Classics, Harvard University, Cambridge, MA.

Flaig, Egon. 1994. "Das Konsensprinzip im homerischen Olymp: Überlegungen zum göttlichen Entscheidungsprozess Ilias 4.1-72," Hermes 122 (1): 13-31.

---. 1993. “Die spartanische Abstimmung nach der Lautstärke: Überlegungen zu Thukydides 1,87." Historia 42(2): 139-60.

Gernet, Louis. 1948. "Jeux et droit (remarques sur le XXIIIe chant de l'Iliade)." Revue historique de droit français et etranger 26: 177-88. 
Graham, George J., Jr. 1984. “Consensus.” In Social Science Concepts: A Systematic Analysis, ed. G. Sartori. Beverly Hills, CA: Sage. Pp. 89-124.

Hentze, C. 1905. “Die Chorreden in den homerischen Epen.” Philologus 64: 254-68.

Higbie, Carolyn. 2003. The Lindian Chronicle and the Greek Creation of their Past. Oxford: Oxford University Press.

de Jong, Irene J. F. 1987. "The Voice of Anonymity: tis-Speeches in the Iliad.” Eranos 85(2): 69-84.

Keil, Bruno. 1916. EIPHNH: Eine philologisch-antiquarische Untersuchung. Leipzig: B. G. Teubner.

Kirk, G. S. 1985. The Iliad: A Commentary, vol. 1. Cambridge: Cambridge University Press.

---. 1978. "The Formal Duels in Books 3 and 7 of the Iliad." In Homer: Tradition and Invention, ed. B. C. Fenik. Leiden: E. J. Brill. Pp. 18-40.

Létoublon, Françoise. 1995. "Said over the Dead: or Tant de marbre parlant sur tant d'ombres." Arethusa 28: 1-19.

Lévêque, Pierre and Pierre Vidal-Naquet. 1996 (1964). Cleisthenes the Athenian: An Essay on the Representation of Space and Time in Greek Political Thought from the End of the Sixth Century to the Death of Plato. Atlantic Highlands, NJ: Humanities Press.

Low, Polly. 2007. Interstate Relations in Classical Greece: Morality and Power. Cambridge: Cambridge University Press.

Mackie, Hilary. 1996. Talking Trojan: Speech and Community in the Iliad. Lanham, MD: Rowman \& Littlefield. 
Nenci, Giuseppe. 1981. "La neutralità nella Grecia antica.” In Studî sui rapporti interstatali nel mondo antico, eds. S. Cataldi, M. Moggi, G. Nenci, and G. Panessa. Pisa: Scuola normale superiore. Pp. 147-60.

Plescia, Joseph. 1970. The Oath and Perjury in Ancient Greece. Tallahassee, FL: Florida State University Press.

Seaford, Richard. 1994. Reciprocity and Ritual: Homer and Tragedy in the Developing City-State. Oxford: Clarendon Press.

Smyth, Herbert Weir. 1999 (1926). Aeschylus, vol. 2. Loeb Classical Library. Cambridge, MA: Harvard University Press.

Vernant, Jean Pierre. 1982 (1962). The Origins of Greek Thought. Ithaca, NY: Cornell University Press.

Wilamowitz-Moellendorf, Ulrich von. 1920. Die Ilias und Homer. Berlin: Weidmann.

Wilson, John R. 1979. “KAI KE TI $\Omega \Delta$ ’ EPEEI: An Homeric Device in Greek Literature.” Illinois Classical Studies 4: 1-15. 